\title{
Immunológiai eltérések kimutatása laboratóriumi módszerekkel primer immunhiányos betegségekben
}

\author{
Nagy Gábor dr. \\ Debreceni Egyetem, Általános Orvostudományi Kar, Laboratóriumi Medicina Intézet, Debrecen
}

\begin{abstract}
A primer immunhiányos betegségekben az immunrendszer hibás múködését genetikai eltérés okozza. A kezelőorvos a klinikai tünetek, jelek, a családi anamnézis és a kórokozó-kimutatás eredményei alapján veti fel a lehetséges diagnózisokat. A gyanú igazolásához nagy segítséget ad, ha az érintett immunológiai funkció in vitro diagnosztikai módszerekkel tesztelhetố. A közlemény az antitestválasz, a T-sejtek, a phagocytafunkció, a komplementszisztéma és a veleszületett immunrendszer egyéb elemeinek vizsgálatára alkalmas szúrő, megerősító és betegségspecifikus laboratóriumi módszereket foglalja össze, nem taglalva a végső diagnózist megadó genetikai teszteket.
\end{abstract}

Orv Hetil. 2018; 159(49): 2087-2094.

Kulcsszavak: immundeficientia, veleszületett immunhiányos betegség, laboratóriumi vizsgálat, laboratóriumi diagnosztika, laboratóriumi kivizsgálás

\section{Laboratory evaluation of immunological dysfunctions in primary immunodeficiency diseases}

In primary immunodeficiencies, the malfunction of the immune system is caused by genetic alterations. The physician proposes the most probable diagnosis based on symptoms, clinical signs, the family history and the results of the pathogen identification. To confirm this clinical suspicion, it is essential that the immunological malfunction be tested using in vitro diagnostic procedures. This paper summarizes the screening, confirmatory and disease-specific laboratory methods capable of testing the antibody response, the $\mathrm{T}$ cells, the phagocytic function, the complement system and other components of the innate immune system. The genetic tests necessary to make the final diagnosis are beyond the scope of this publication.

Keywords: immunologic deficiency syndromes, primary immunodeficiency, laboratory marker, laboratory diagnosis, clinical laboratory testing

Nagy G. [Laboratory evaluation of immunological dysfunctions in primary immunodeficiency diseases]. Orv Hetil. 2018; 159(49): 2087-2094.

(Beérkezett: 2018. július 25.; elfogadva: 2018. szeptember 7.)

\section{Rövidítések}

ALPS = autoimmun lymphoproliferativ szindróma; BAFF-R = (B cell-activating factor receptor) a B-sejt-aktiváló faktor receptora; $\mathrm{BrdU}=$ bróm-dezoxiuridin; $\mathrm{BTK}=$ Bruton-féle tirozinkináz; CARDll = (caspase recruitment domain-containing protein 11) kaszpáztoborzó domént tartalmazó protein-11; $\mathrm{CD}=$ (cluster of differentiation) differenciációs klaszter; CFSE $=($ carboxyfluorescein succinimidyl ester $)$ karboxifluoreszcein szukcinimidil-észter; $\mathrm{CMC}=$ (chronic mucocutan candidiasis $)$ krónikus mucocutan candidiasis; CVID $=($ common variable immunodeficiency) gyakori változatos immunhiány; $\mathrm{DHR}=$ dihidrorodamin; ELISA = (enzyme linked immunosorbent assay) enzimkapcsolt immunszorbens vizsgálat; GAT = granulocytaagglutinatiós teszt; GIFT = granulocyta-immunfluoreszcenciás teszt; ICOS = (inducible costimulator) indukálható kostimulátor; $\operatorname{IgA}=$ immunglobulin $\mathrm{A} ; \operatorname{IgD}=$ immunglobulin $\mathrm{D} ; \mathrm{IgE}=$ immunglobulin $\mathrm{E} ; \mathrm{IgG}=$ immunglobulin $\mathrm{G} ; \mathrm{IgM}=$ immunglobulin M; IPEX = immundiszreguláció, polyendocrinopathia, enteropathia, X-hez kötött; KREC = (kappa-deleting recombination excision circle) kappa-rekombináció-kivágási kör; $\mathrm{LAD}=$ (leukocyte adhesion deficiency) fehérvérsejtadhaesiós defektus; LOCID = (late onset combined immuno- 
deficiency) késői kezdetű kombinált immunhiányos állapot; $\mathrm{MHC}=($ major histocompatibility complex $)$ fó hisztokompatibilitási komplex; $\mathrm{NADPH}=$ (nicotinamide adenine dinucleotide phosphate) nikotinamid-adenin-dinukleotid-foszfát; $\mathrm{NBT}=$ (nitro-blue tetrazolium chloride) nitrokék-tetrazólium-klorid; $\mathrm{NF}-\mathrm{KB}=$ nukleáris faktor-kappa-B; NK = (natural killer cell) természetes ölősejt; PCR $=$ (polymerase chain reaction $)$ polimeráz-láncreakció; SCID $=($ severe combined immunodeficiency) súlyos kombinált immunhiányos állapot; TACI $=$ (transmembrane activator and calcium-modulating cyclophilin-ligand interactor) transzmembránaktiváló és kalciummodulátor ciklofilinligand-közremúködő; TCR $=($ T-cell receptor $)$ T-sejt-receptor; TLR $=$ (Toll-like receptor $)$ Toll-szerú receptor; TREC $=(\mathrm{T}$ cell receptor excision circle $)$ T-sejt-receptor-kivágási kör; $\mathrm{XLA}=(\mathrm{X}$-linked agammaglobulinemia $) \mathrm{X}$-hez kötött agammaglobulinaemia

A veleszületett immunhiányos betegségekben az immunrendszer érintett részének eltéréseit laboratóriumi módszerekkel igazolhatjuk. A meglehetősen komplex rendszer betegség által befolyásolt, feltehetően kórosan múködő elemeinek kiválasztása a kezelőorvos feladata, ami a klinikai tünetek, jelek, valamint a képalkotó vizsgálatok és a kórokozó-kimutatás eredményei alapján történik. A felhasználható in vitro diagnosztikai tesztek áttekintéséhez érdemes azokat az immunrendszer vizsgált komponense szerint csoportosítani. Ezek alapján megkülönböztethetjük az antitestválasz, a T-sejtek, a phagocytafunkció, a komplementrendszer és a veleszületett immunrendszer egyéb elemeinek defektusát kimutató laboratóriumi vizsgálatokat. A klinikai kép és az igazolt immunológiai eltérés vezet el a feltételezett hibás génhez, melynek azonosítása nukleinsavalapú (genetikai) tesztekkel történik [1-4].

Az immunhiányos állapotok laboratóriumi diagnosztikájának nehézsége, hogy ezek az állapotok ritkák, sok esetben még országos centrumban sem érhető el a fenntartáshoz szükséges vizsgálatszám, amely pedig a megfelelő minőségú és kellően rövid időn belül elkészülő eredményekhez elengedhetetlen. Nagy segítséget jelent az immunológiai profilú laboratóriumok együttmúködése; célszerü az országon belüli, de akár nemzetközi munkamegosztás kialakítása. Érdemes ezeket a teszteket rendszeresen karbantartott adatbázisba foglalni, mely segítséget nyújt a kezelőorvosnak a vizsgálat megtalálásában. Magyarországon ilyen a Magyar Laboratóriumi Diagnosztikai Társaság által üzemeltetett regiszter, mely a végző laboratóriumok adatai mellett a szükséges mintatípusról és a leletezési időről is tájékoztatást ad (http:// mldt-regiszter.hu, felhasználónév: klinikum, jelszó: klinik1234). Sajnos a primer immundefektusok kivizsgálásához szükséges vizsgálatok teljes spektruma nem érhetô el a hazai orvosdiagnosztikai laboratóriumokban.

Az egyes immunológiai kompartmentek vizsgálatának tesztjei hierarchikus rendszert alkotnak, melyben legelöl áll egy szűrő jellegű teszt; ennek kóros eredménye alapján további vizsgálatok indokoltak, melyek egyre részletesebb kivizsgálást tesznek lehetővé. Az ilyen algoritmusalapú megközelítés egyben a gazdaságosságot is szolgálja (1. táblázat).

1. táblázat |A primer immunhiányos állapotok kimutatására szolgáló szűrő, megerősítő és betegségspecifikus laboratóriumi vizsgálatok

\begin{tabular}{|c|c|c|c|}
\hline Immunológiai funkció & Szűrő jellegű teszt & Megerősítő teszt & Betegségspecifikus teszt \\
\hline Antitesttermelés & $\begin{array}{l}\text { - IgG, IgA, IgM, IgE } \\
\text { - Szérumglobulinrés } \\
\text { - Proteinelektroforézis } \\
\text { - KREC }\end{array}$ & $\begin{array}{l}\text { - B-sejt-szám } \\
\text { - B-sejt éretlen alakjai, naiv és } \\
\text { memóriasejtek } \\
\text { - IgG-alosztályok } \\
\text { - Isohaemagglutinintiter } \\
\text { - Antigénspecifikus antitestválasz }\end{array}$ & $\begin{array}{l}\text { - Sejtfelszíni vagy intracellularis fehérje } \\
\text { hiányának vagy diszfunkciójának } \\
\text { kimutatása áramlási citometriával } \\
\text { (BTK, CD40L, CD40, ICOS, CD19, } \\
\text { BAFF-R stb.) } \\
\text { - Genetikai vizsgálat }\end{array}$ \\
\hline T-sejt-funkció & $\begin{array}{l}\text { - Vérkép } \\
\text { - Abszolút lymphocytaszám } \\
\text { - TREC }\end{array}$ & $\begin{array}{l}\text { - T-sejt-szám } \\
\text { - T naiv és memóriasejtek, } \\
\text { aktivált állapot } \\
\text { - Lymphocytaproliferatiós teszt }\end{array}$ & $\begin{array}{l}\text { - Sejtfelszíni vagy intracellularis fehérje } \\
\text { hiányának vagy diszfunkciójának, } \\
\text { csökkent apoptózisnak a kimutatása } \\
\text { áramlási citometriával } \\
\text { - Genetikai vizsgálat }\end{array}$ \\
\hline Phagocytafunkció & $\begin{array}{l}\text { - Vérkép } \\
\text { - Abszolút neutrophilgranulocy- } \\
\text { ta-szám }\end{array}$ & $\begin{array}{l}\text { - Adhaesio } \\
\text { - Migráció } \\
\text { - Kemotaxis } \\
\text { - Phagocytosis } \\
\text { - Intracellularis killing } \\
\text { - DHR-teszt }\end{array}$ & $\begin{array}{l}\text { - Sejtfelszíni fehérje hiányának kimutatása } \\
\text { áramlási citometriával (CD18) } \\
\text { - Genetikai vizsgálat }\end{array}$ \\
\hline Komplementrendszer & $\begin{array}{l}\text { - Összkomplement-aktivitás } \\
\text { - C3, C4 }\end{array}$ & & $\begin{array}{l}\text { - Komplementfaktor-aktivitás és -antigén } \\
\text { - Genetikai vizsgálat }\end{array}$ \\
\hline $\begin{array}{l}\text { A veleszületett } \\
\text { immunitás egyéb } \\
\text { funkciói }\end{array}$ & & $\begin{array}{l}\text { - NK-sejt-szám } \\
\text { - Cytotoxicus aktivitás } \\
\text { - TLR-útvonalak vizsgálata } \\
\text { - IgD-meghatározás } \\
\text { - Mevalonsav-ürítés }\end{array}$ & - Genetikai vizsgálat \\
\hline
\end{tabular}




\section{Az antitesttermelés defektusainak laboratóriumi kimutatása}

A primer immunhiányos betegségek körülbelül felében az elsődleges eltérés a nem megfelelő ellenanyag-termelés. Ennek gyanúja esetén az első lépés a különböző immunglobulinosztályok (IgG, IgA, IgM, IgE) koncentrációjának meghatározása. Bizonyos esetekben szükség van az immunglobulin G-alosztályok és egyes antigénspecifikus antitestek meghatározására is [1].

\section{Szérumglobulinvés}

A szérumglobulinrés (számított globulin) a szérumtotálfehérje és az albuminkoncentráció különbsége, melynek nagy részét az immunglobulinok adják, így jó korrelációt mutat elsősorban az immunglobulin G koncentrációjával. Haszna az immunglobulinok mérésének elterjedése miatt olyan esetekre korlátozódik, amikor valamilyen okból összfehérje- és albuminvizsgálat történik, de IgG-, IgA-, IgM-mérés nem. Jelentősége nemcsak az emelkedett különbségnek van, amikor monoclonalis gammopathiára vagy autoimmun betegségre kell gondolni, hanem az alacsony értéknek is. Egy tanulmányban a $<18$ g/l számított globulinértékkel rendelkező betegek 89\%-ánál 6 g/l alatti IgG-szintet lehetett mérni [5].

\section{Totál-IgG, -IgA, -IgM, -IgE mérése}

A g/l koncentrációtartományba eső G-, A-, M-osztályok mérése fényszóráson alapuló turbidimetriás módszerrel is lehetséges. Analitikai kihívást egyedül az IgA-izotípus jelent: olyan módszer választandó, amelynek detektálási küszöbe 0,06 g/l vagy az alatti. Az IgE mennyisége a többi osztálynál nagyságrendekkel alacsonyabb, ezért érzékenyebb ELISA-, nefelometriás vagy kemilumineszcenciás módszer beállítását igényli. Az eredmény kiadása kIU/l mértékegységben történik. Mindegyik immunglobulinosztályra igaz, hogy referenciatartománya életkorfüggő, mivel az újszülött, csecsemő, gyermek éretlen immunrendszere a felnőtténél kevesebb ellenanyagot termel még. IgG-izotípus esetén a placentán átjutó ellenanyag hozzáadódik az újszülött által megtermelt mennyiséghez, a legalacsonyabb szérumkoncentrációkat 3-9 hónapos életkorban mérhetjük $[6,7]$.

A leggyakrabban megfigyelhető eltérés a szelektív IgA-hiány; komplett változatában a szint $<0,06 \mathrm{~g} / 1$, és sok esetben nem jár tünetekkel. A leggyakoribb szimptómás immunhiányos állapotban, a gyakori változatos immundefektusban (CVID) az IgG és az IgA vagy IgM szintje a referenciatartomány alatt van. Hiper-IgMszindróma fennállásakor az osztályváltás hibája miatt az IgG- és IgA-szint alacsony, míg az IgM magas vagy normális. Hiper-IgE-szindróma esetén magas, sokszor extrém magas totál-IgE-koncentrációt mérhetünk $[3,8,9]$.

\section{Az immunglobulin G-alosztály mérése}

A keringésben 60-70\% IgG1, 20-30\% IgG2, 5-8\% IgG3 és 1-3\% IgG4 található. A négy alosztály közül az IgG4 koncentrációja a referenciatartomány alatti érték esetén olyan alacsony, hogy a meghatározás csak nefelometriával kivitelezhető. Az indikációt az alosztály-deficientia gyanúja jelenti. Gyanú esetén az alosztályok mérését akkor is el kell végezni, ha a totál-IgG a referenciatartományon belül található, mivel teljes alosztályhiány esetén sem feltétlenül látható csökkent IgG-koncentráció. Alosztály-deficientia gyakran jelentkezik együtt szelektív IgA-hiánnyal, ezért érdemes ebben az állapotban is vizsgálni. Az IgG2 a tokos baktériumokkal szembeni védekezésben fontos, teljes hiánya esetén az egyén például Streptococcus pneumoniae vagy Haemophilus influenzae által okozott fertőzésre hajlamos $[1,7]$.

\section{Specifikus antitestpálasz}

A specifikus antitestek vizsgálatával arra a kérdésre kapunk választ, hogy a szervezet képes-e bizonyos szénhidrát- és proteinantigének ellen megfelelő ellenanyag-termeléssel reagálni. Idetartozik a spontán megjelenő anti-A- és antiB-ellenanyagok (isohaemagglutinin) vizsgálata. A Landsteiner-szabályoknak megfelelő termelés B-sejt-defektusok esetén csökkent, amit a titer haemagglutinatiós próbával történő meghatározásával mutathatunk ki.

A dokumentált fertőzés vagy oltás után a kórokozó szénhidrát- vagy proteinantigénje elleni antitesttermelés elmaradása szintén a kóros B-sejt-funkció jele. A szénhidrátantigének elleni védekezőképességet a Pneumococcus, Haemophilus, Meningococcus tokpoliszacharidák elleni specifikus ellenanyag meghatározásával vizsgálhatjuk. A kötelező oltás miatt a tetanusz- és diftériatoxoid-ellenes antitest mérése használható a fehérjeantigén által kiváltott válasz megítélésére. Az antitestkoncentrációk értelmezésében az úgynevezett protektív szinttel való összevetés segíthet, de a megítélés még így sem egyértelmú. Egyrészt a védettségi szint módszerfüggő, másrészt a szakirodalomban sincs egyöntetüen elfogadott határérték. Arra is van adat, hogy a védettséget pontosabban értékelhetjük, ha az eredményt referenciatartomány-sávokhoz hasonlítjuk. Figyelembe kell azt is venni, hogy a korábban kapott oltásra adott válasz nem feltétlenül tükrözi a jelenlegi válaszkészséget, inkább az immunológiai memóriát jellemzi. A status quo megítélésére újraoltás történhet, a 3-4 hét alatt bekövetkező, az oltás előttihez képest négyszeres szintemelkedés általánosan elfogadott mint megfelelő válasz. Ha azonban a prevakcinációs szint magas, akkor ilyen mértékű növekedést még jó válaszkészség esetén sem várhatunk $[2,10,11]$.

\section{B-sejt-szám, B-sejt-alcsoportok}

A lymphocyta-alosztályok áramlási citometriás mérésével lehetőség van a csökkent B-sejt-arány vagy a még infor- 
matívabb abszolút B-sejt-szám meghatározására. Congenitalis agammaglobulinaemiák esetén a B-sejt-szám nagyon alacsony (az arány <1\%), a B-sejtek érési blokkjának megfelelően. A B-sejteken belüli alcsoportoknak a CVID kategorizálásában van szerepük. Több klasszifikációs séma is elérhető (Freiburg, Paris, EUROclass), melyek a totál-B-sejt-arány mellett a naiv $(\mathrm{IgD}+/ \mathrm{IgM}+/$ CD27-), a marginális zóna (IgD+/IgM+/CD27+), az osztályváltáson átesett memória (IgD-/IgM-/CD27+) és más B-sejt-szubpopulációk alapján differenciálnak. Újabban leírt CVID-változat a késői kezdetű kombinált immundeficientia (LOCID, late onset combined immunodeficiency), melyre akkor gondolhatunk, ha opportunista fertőzések és alacsony $(<0,2 \mathrm{G} / 1)$ CD4+ T-sejt- szám is kimutatható. A CARDll funkciónyerő mutációi esetén a B-sejt-szám emelkedett a folyamatos NF- $\kappa \mathrm{B}$ aktiváció miatt $[4,12-14]$.

\section{Speciális áramlási citometriás vizsgálatok}

Az agammaglobulinaemiák nagyobb része X-hez kötött betegség, melyet a BTK-gén eltérése okoz. A BTK-fehérjét intracellularis jelöléssel áramlási citometria segítségével mutathatjuk ki. Mivel a betegeknek alacsony a Bsejt-számuk, a tesztet monocytákon vagy vérlemezkéken kell elvégezni. Hiányzó vagy nagyon alacsony BTK-protein-expresszió XLA-t valószínűsít. A normálmennyiségü fehérje ugyanakkor nem zárja ki a betegséget, mivel

2. táblázat |A kombinált immundefektusok csoportosítása a lymphocyták áramlási citometriás fenotipizálásával [3, 18]

\begin{tabular}{|c|c|c|c|}
\hline Fenotípus & Betegség & Gén & Fehérje \\
\hline \multirow[t]{2}{*}{$\mathrm{T}-/ \mathrm{B}+/ \mathrm{NK}-$} & Közös gamma-lánc-deficientia ${ }^{*}$ & IL2RG & $\begin{array}{l}\text { IL2-, IL4-, IL7-, IL9-, IL15-, IL21-receptor közös } \\
\text { gamma-lánc }\end{array}$ \\
\hline & JAK3-deficientia & JAK3 & Janus-kináz-3 \\
\hline \multirow[t]{6}{*}{$\mathrm{T}-/ \mathrm{B}-/ \mathrm{NK}+$} & $\underline{\text { RAGl-deficientia }}$ & RAGl & RAG-1 \\
\hline & RAG2-deficientia & RAG2 & RAG-2 \\
\hline & Artemisdeficientia & DCLREIC & Artemis \\
\hline & DNS-ligáz-IV-deficientia & LIG4 & DNS-ligáz-IV \\
\hline & DNS-PKcs-deficientia & PRKDC & DNS-dependens proteinkináz, katalitikus alegység \\
\hline & Cernunnos/XLF deficientia & NHEJl & Cernunnos/XRCC4-szerű faktor \\
\hline \multirow[t]{5}{*}{$\mathrm{T}-/ \mathrm{B}+/ \mathrm{NK}+$} & $\underline{\text { IL7-receptor- } \alpha \text {-lánc-deficientia }}$ & IL7RA & IL7-receptor- $\alpha$-lánc \\
\hline & CD3-komplex-deficientia & $\begin{array}{l}\text { CD3D, CD3E, } \\
\text { CD3Z, CD3G }\end{array}$ & $\mathrm{CD} 3 \delta, \mathrm{CD} 3 \varepsilon, \mathrm{CD} 3 \zeta, \mathrm{CD} 3 \gamma$ \\
\hline & CD45-deficientia & PTPRC & $\mathrm{CD} 45$ \\
\hline & CoroninlA-deficientia & COROIA & CoroninlA \\
\hline & PNP-deficientia & PNP & Purin-nukleozid-foszforiláz \\
\hline \multirow[t]{2}{*}{$\mathrm{T}-/ \mathrm{B}-/ \mathrm{NK}-$} & $\underline{\text { ADA-deficientia }}$ & $\mathrm{ADA}$ & Adenozin-deamináz \\
\hline & Reticularis dysgenesis & AK2 & Adenilát-kináz-2 \\
\hline \multirow[t]{3}{*}{$\mathrm{CD} 4+/ \mathrm{CD} 8-/ \mathrm{B}+/ \mathrm{NK}+$} & ZAP70-deficientia & ZAP70 & Zéta-lánc-asszociált proteinkináz-70 \\
\hline & CD8-deficientia & CD8A & CD8- $\alpha$-lánc \\
\hline & MHCI-deficientia & $\begin{array}{l}\text { TAP1, TAP2, } \\
\text { TAPBP, B2M }\end{array}$ & TAP1-, TAP2-, TAP-kötő fehérje, $\beta 2$-mikroglobulin \\
\hline \multirow[t]{2}{*}{$\mathrm{CD} 4-/ \mathrm{CD} 8+/ \mathrm{B}+/ \mathrm{NK}+$} & MHCII-deficientia & $\begin{array}{l}\text { CIITA, RFXANK, } \\
\text { RFX5, RFXAP }\end{array}$ & MHC class II transzaktivátor, RFXANK, RFX5, RFXAP \\
\hline & LCK-deficientia & LCK & Tirozin-proteinkináz Lck (p56lck) \\
\hline
\end{tabular}

* A leggyakoribb öt súlyos kombinált immundefektus aláhúzva.

ADA = adenozin-deamináz; AK2 = adenilát-kináz-2; CIITA = (class II, major histocompatibility complex, transactivator) II. osztályú fó hisztokompatibilitási komplex transzaktivátora; DCLRE1C = (DNA cross-link repair 1C) DNS-keresztkötés-kijavító lC; DNA-PK = DNS-függő proteinkináz; JAK3 = Janus-kináz-3; LCK = lymphocyta-specifikus protein tirozin kináz; LIG4 = DNS-ligáz-4; NHEJl = (non-homologous endjoining 1) nem-homológ vég-a-véghez illesztés 1 ; PNP = purin-nukleozid-foszforiláz; PRKDC = (protein kinase, DNA-activated, catalytic polypeptide) DNS-függő proteinkináz katalitikus alegysége; PTPRC $=$ (protein tyrosine phosphatase, receptor type C) receptor-típusú tirozinprotein-foszfatáz C; RAG = (recombination activating genes) rekombinációaktiváló gén; RFX5 = (regulatory factor X5) X5 szabályozó faktor; RFXANK = (regulatory factor $\mathrm{X}$ associated ankyrin containing protein $) \mathrm{X}$ szabályozó faktor kapcsolt ankirintartalmú fehérje; RFXAP $=($ regulatory factor X-associated protein) X szabályozó faktorhoz kapcsolt fehérje; TAPl $/ 2=($ transporter associated with antigen processing $1 / 2)$ antigénfeldolgozáshoz kapcsolódó szállítófehérje $1 / 2 ; \mathrm{TAPBP}=($ TAP binding protein $)$ TAP-kötő fehérje, XLF = XRCC4-szerú faktor; XRCC4 = X-ray repair cross-complementing protein 4 
egyes betegekben nemfunkcionális géntermék expreszszálódik. A vizsgálat ugyanakkor a hordozó állapot felismerésére is alkalmas [15].

Hiper-IgM-szindrómában a B-sejtek differenciálódásának késői szakasza, az immunglobulinizotípus-váltás érintett. A leggyakoribb formájában a T-sejtek felszínén található CD40-ligand (CD40L, CD154) molekula csökkent expressziója mutatható ki stimuláció után. Néhány esetben a fehérje jelen van, de nem múködik, emiatt a normális sejtfelszíni jelenlét nem zárja ki a betegséget ebben az esetben sem. A múködésképtelen proteint és a fehérje hiányát is felismerhetjük egy olyan CD40-Ig komplex hozzáadásán alapuló teszttel, mely a CD40L molekula funkcionális vizsgálatára alkalmas. A szindróma kialakulhat úgy is, hogy a CD40 nem jelenik meg a Bsejtek felszínén, amit szintén meg lehet erősíteni áramlási citometriás elven. A hiper-IgM-szindróma többi formáját csak genetikai teszttel lehet igazolni [16].

A CVID-csoporton belül az egyének egy kis részében sikerült igazolni genetikai hibát (ICOS, CD19, BAFF-R, TACI). Az első három esetén az expresszió megváltozását kimutathatjuk citométer segítségével [17].

\section{Kappa-rekombináció-kivágási kör (kappa-deleting recombination excision circle, KREC)}

A KREC olyan körkörös DNS-darab, mely a kappakönnyưlánc-gén átrendeződése során keletkezik. Polimeráz-láncreakció (PCR) segítségével száma meghatározható, ezáltal a B-sejt-fejlődésről szolgáltat információt, hasonlóan a T-sejt-receptor-kivágási kör ( $\mathrm{T}$ cell receptor excision circle, TREC) vizsgálatához. A B-sejtek fejlődési zavarával járó állapotok (XLA, ataxia teleangiectasia, Nijmegen breakage szindróma) szúrésére alkalmas, az újszülöttkori szûrés részévé válhat (hazánkban jelenleg nem elérhető vizsgálat) $[18,19]$.

\section{A T-sejt-defektusok laboratóriumi kimutatása}

\section{T-sejt-szám, T-sejt-alcsoportok}

A T-sejtek számára a vérképvizsgálattal kapott abszolút lymphocytaszámból is következtetni lehet, mivel a keringő lymphocyták nagy része T-sejt. A lymphopenia általában a T-sejt-szám csökkenéséből adódik. A lymphopenia megítéléséhez is korspecifikus normáltartományok szükségesek. Az áramlási citometriás meghatározás természetesen pontosabb eredményt ad a T-sejt-számról, emellett lehetőség van a CD4+ és CD8+ T-sejtek és a naiv és a memóriasejtek számáról, illetve a T-lymphocyták aktiváltságáról is képet kapnunk. A súlyos kombinált immundefektus (SCID) a legújabb osztályozás szerint már csak 0,3 G/1 alatti CD3+ T-sejt-szám, tehát flow cytometria alapján mondható ki, a vérképből származó alacsony lympho- cytaszám ehhez nem elegendő. A lymphocyta-alcsoportok vizsgálatának nagy jelentősége van a SCID differenciálásában, segítségével elkülöníthetjük a $\mathrm{T}-/ \mathrm{B}+/ \mathrm{NK}+$, a $\mathrm{T}-/ \mathrm{B}+/ \mathrm{NK}-$, a $\mathrm{T}-/ \mathrm{B}-/ \mathrm{NK}+$, a $\mathrm{T}-/ \mathrm{B}-/ \mathrm{NK}-$ és egyéb formákat. A CD4+ T-sejtek hiánya esetén MHCII-, míg a CD8+ T-lymphocyták hiánya esetén MHCI-deficientiára kell gondolnunk (2. táblázat). A T-sejtek alacsony számát láthatjuk egyes szindrómás kombinált immundefektusokban, például Di George-szindrómában, WiskottAldrich-szindrómában, ataxia teleangiectasiában. Autoimmun lymphoproliferativ szindrómában (ALPS) a CD4-/CD8- kettős negatív $\alpha / \beta$ T-sejtek felszaporodnak. TCR- $\alpha$-deficientia esetén pedig minden T-sejt $\gamma / \delta$ receptort hordoz. A felszíni mellett intracellularis jelölés is szükséges az IPEX (immundiszreguláció, polyendocrinopathia, enteropathia, X-hez kötött) szindrómában a $\mathrm{CD} 3+/ \mathrm{CD} 4+/ \mathrm{CD} 25+/ \mathrm{FOXP} 3+$ regulatorikus T-sejtek (Treg) elégtelen számának kimutatásához, amely az immunrendszer szabályozásának zavarához vezet. A Tregsejtek jelenléte azonban nem zárja ki az IPEX-szindrómát, mivel bizonyos mutációk a FOXP3-protein expreszszióját nem befolyásolják, de a sejtek múködőképessége nem megfelelö $[4,12,15,17]$.

\section{T-sejt-funkció}

A T-sejteket antigének és aspecifikus mitogének hozzáadásával osztódásra késztethetjük (blastos transzformáció), ami a funkcióképességük in vitro megítélését teszi lehetővé. A proliferatiós index meghatározásához már nem szükséges a radioaktív tríciummal jelölt timidint tartalmazó nukleinsavak használata, bróm-dezoxiuridin (BrdU)- vagy karboxifluoreszcein-szukcinimidil-észter (CFSE)-alapú reagensek felhasználásával éppúgy elvégezhetjük. A T-sejt-funkció tesztjeként tekinthetünk a stimuláció után kimutatott intracitoplazmatikus citokintermelésre is, amellyel a Th1/Th2/Th17 funkcionális szubpopulációkat határozhatjuk meg. Áramlási citométer segítségével megvizsgálhatjuk a jelátvitelben részt vevő proteinek foszforiláltságát is (foszfo-flow). A STATl transzkripciós faktor esetén mind a funkcióvesztő (intracellularis baktérium- és vírusfertőzések), mind a funkciónyerő (CMC) mutációinak hatása kimutatható így $[12,20,21]$.

\section{Egyéb laboratóriumi módszerek}

Adenozin-dezamináz- vagy purin-nukleozid-foszforilázhiánynak megfelelő fenotípus esetén a gyanúnkat az alacsony enzimaktivitás vörösvértestekben történő kimutatásával erősíthetjük meg. Nagyobb méretű (több gént érintő) genetikai eltérés elvétve fordul elő a primer immunhiányos állapotok között, ezek citogenetikai módszerekkel mutathatók ki (fluoreszcens in situ hibridizáció, esetleg kromoszómasávozás). Idetartozik a 22q11.2-deletio Di George-szindrómában vagy a 10pl3-pl4-deletiós szindróma. 


\section{A phagocytafunkció defektusainak laboratóriumi vizsgálata}

A neutrophil granulocyták fontos szerepet töltenek be a védekezésben, elsősorban az extracellularisan szaporodó baktériumok és gombák elpusztításában. Fő fegyverük a phagocytosis, azonban nem szabad elfeledkeznünk a különböző baktericid és fungicid peptidek és fehérjék szerepéről és a nem oly régen felfedezett netosis jelenségéről sem. Jelenleg laboratóriumi szempontból a számbeli eltérést, illetve az adherencia, kemotaxis, phagocytosis és intracellularis killing folyamatát tudjuk részletesen vizsgálni $[20,22]$. Sajnálatos tény, hogy a phagocytafunkció laboratóriumi vizsgálatai Magyarországon csak részlegesen érhetők el rutindiagnosztikai célból még az immunológiai irányban specializálódott centrumokban is.

\section{A neutrophil granulocyták számbeli eltérései}

A vérképautomaták korában a neutrophil százalékos aránya helyett az abszolút szám használata javasolt, melyet nem befolyásol a többi fehérvérsejt-populációban bekövetkezett változás. A számbeli eltérések közül immunhiányos állapot esetén elôször az alacsony szám juthat eszünkbe, kivételt jelent a leukocytaadhaesiós defektusban jelentkező neutrophilia. A neutropenia az abszolút neutrophilszám alapján lehet enyhe $(1,0-1,5 \mathrm{G} / \mathrm{l})$, közepesen súlyos $(0,5-1,0 \mathrm{G} / \mathrm{l})$ és súlyos $(<0,5 \mathrm{G} / \mathrm{l})$. Az alacsony szám oka lehet a csökkent képzés, csontvelői apoptózis, a kijutás zavara (myelocathexis) vagy fokozott pusztulás a periférián. Ciklikus neutropeniában a granulocytaszám periodikusan változik: körülbelül 21 naponta 3-6 napig alacsony a sejtszám. Kimutatásához négy-hat hétig heti 2-3 alkalommal szükséges meghatározni a neutrophil granulocyták számát [23].

A fokozott pusztulás lehet antitestmediált folyamat is, amikor valamely sejtfelszíni antigénhez kapcsolódó ellenanyag jelenik meg a páciens vérében. A congenitalis neutropeniák csoportjában neutrophil granulocyta elleni antitest nem detektálható, sok immunhiányos állapotban jelenik meg azonban autoimmunitás, melynek része lehet neutrophilellenes autoantitest termelése. Ezeket az antitesteket a beteg neutrophil sejtjein (direkt teszt) vagy a szérumából (indirekt teszt) is ki lehet mutatni. Az utóbbi valamivel egyszerúbb, ezért jobban elterjedt, bár kevésbé érzékeny a direkt változatnál. A metodikát illetően a granulocyta-immunfluoreszcenciás teszt (GIFT) és a granulocytaagglutinatiós teszt (GAT) egyidejü használata ajánlott szúrésre. A granulocyta-immunfluoreszcenciás vizsgálatnak mikrotiterlemezre (sejtes ELISA) és áramlási citométerre (flow-GIFT) adaptált változata is létezik. A kimutatott antitest antigénspecificitásának meghatározása a granulocytaantigének monoclonalis antitesttel történő immobilizációján alapuló (MAIGA) vagy multiplex mikrogyöngy módszerrel lehetséges [4, 24-26].

\section{A neutrophildiszfunkció kimutatása laboratóriumi módszerekkel}

Az érpályából való kijutás első lépése az endothelfelszínhez való kitapadás (adhaesio). Az adherencia képessége vizsgálható fedetlen, valamilyen extracellularis mátrix fehérjével vagy endothelsejtekkel fedett 96 lyukú lemezen. A kitapadásban részt vevő fóbbb fehérjék (CDl la/CDl8, CDllb/CD18, CDllc/CD18) sejtfelszíni meglétét külön-külön is analizálhatjuk áramlási citometriás módszerrel. A leggyakoribb leukocytaadhaesiós defektusban (LADI) a $\beta 2$-integrincsaládba tartozó molekulák $\beta$-alegységének (CD18) sejtfelszíni expressziója alacsony.

A migráció és a kemotaxis vizsgálata klasszikusan Boyden-kamrában történik. A kamra két rekesze a neutrophilek számára átjárható membránnal van elválasztva. Az egyik rekeszbe kerülnek a beteg szeparált sejtjei, míg a másikba valamilyen hívójelként használható anyag (például zimozánnal aktivált szérum, $\mathrm{N}$-formil-metionil-leucil-fenilalanin). Rövid inkubációs időnél a filterbe, hoszszú inkubációs időnél a második rekeszbe vándorolt sejtek számát határozzuk meg. A modernebb változatok sokkamrás lemezt, esetleg fluoreszcensen jelölt sejteket alkalmaznak.

A phagocytosist vizsgálhatjuk mikroszkóp alatt, például a bekebelezett baktérium/gomba particulumok megszámlálásával. Manapság inkább az internalizált, fluoreszcensen jelölt baktériumok áramlási citométerrel történő meghatározása használatos.

A phagocytosis még nem jelenti a baktérium elpusztítását, ezért az intracellularis killing vizsgálata is javasolt. Hagyományos módszere a neutrophil granulocyták lizálása után a sejten belüli, életképes baktériumok számának meghatározása telepképzés alapján. Mivel a neutrophil granulocyták fö ölőmechanizmusa a reaktívoxigén-szabadgyökök termelése, ennek tesztelése talán a legelterjedtebb funkcionális vizsgálat. Fénymikroszkópos, tárgylemezen kivitelezhetó citokémiai reakción alapul a nitrokék-tetrazólium-klorid (NBT)-vizsgálat, spektrofotometriás teszt a szuperoxid-anion-termelést kimutató citokróm-C-redukció-gátlási teszt, kemilumineszcenciával vizsgálható a teljes vérhez adott luminol oxidációja. A legkorszerúbben azonban ezt a fázist is áramlási citometriával vizsgálhatjuk: a sejtekbe bejutó dihidrorodaminból az oxidáció hatására fluoreszkáló rodamin képződik. Ezek közül bármelyik teszttel kimutatható a krónikus granulomatosus betegségre jellemző deficiens oxidatív burst, amelyet a NADPH-oxidáz valamelyik alegységének (gp91, p22, p40, p47, p67) hiánya okoz [2, 20, 22, 27].

Megemlítendő, hogy a gyakori myeloperoxidázhiány könnyen kimutatható a vérképautomaták egy részével, mivel a fehérvérsejtek differenciálása részben az enzimaktivitás mérésével történik. Emellett bizonyos esetekben nem tekinthetünk el a kenetértékeléstől sem, például Chédiak-Higashi-szindrómában a kórosan megnagyobbodott granulumokat a hagyományos, panoptikus festéssel is megfigyelhetjük. 


\section{A komplementrendszer defektusainak laboratóriumi vizsgálata}

A komplementrendszer az immunrendszer humoralis részéhez tartozó proteinkaszkád, mely mind a veleszületett, mind a szerzett immunitásban fontos szerepet tölt be. Funkcionális szempontból három útvonalon aktiválódhat: klasszikus, alternatív és lektinútvonalakon keresztül. A komplementrendszer laboratóriumi vizsgálata során kimutathatjuk a komplementfaktorokat funkcionális, illetve antigénsajátosságuk alapján. Az első lépésként sok esetben valamelyik vagy mindhárom útvonal úgynevezett összkomplement-aktivitását határozzuk meg. A hemolitikus vizsgálati változatban a reagensként használt vörösvértest membránjába beépül a membránkárosító komplex, és a kiszabadult hemoglobin fotometriásan mérhetố. Az aktiválás kizárólag a vizsgált útvonalon indul el; a klasszikus út összkomplement-aktivitás mérése (CH50) esetén például a birkavörösvértest felszínéhez kapcsolt immunglobulin, az alternatív útvonal összkomplement-aktivitás mérése (AH50) esetén nyúlvörösvértest indítja el. Ha egy komplementfaktor hiányzik, az érintett útvonalnak megfelelő tesztnél alacsony, leginkább mérhetetlen aktivitást kapunk (3. táblázat). Az eredményből kikövetkeztethetjük, hogy mely faktorok hiányozhatnak, majd az egyes fehérjék aktivitás- vagy antigénszintjét meghatározva azonosítjuk a hiányzó komplementkomponenst [28].

A tüneteket okozó komplementfaktor-deficientiák ritkák, bár ez a fel nem ismerésnek is köszönhető lehet. Az immunhiányos állapot mellett autoimmunitáshoz vezethet a Clq, Clr, Cls, C2, C4 faktorok hiánya, mivel ezek az immunkomplexek eliminációjában is részt vesznek. A komplementrendszer inhibitorainak hiánya kontrollálatlan aktivációt okoz, de másodlagosan a faktorok elhasználódása miatt fertózések is megjelenhetnek. A komplementkomponensek többsége pozitív akutfázis-fehérje, gyulladás esetén megemelkedik a koncentrációjuk [29].

\section{A veleszületett immunrendszer egyéb elemeinek vizsgálata}

\section{NK-sejt-szám és-aktivitás}

A természetes ölősejtek számbeli vagy funkcionális rendellenességére elsősorban herpesz- és humánpapillomavírus-fertőzések esetén kell gondolni. A lymphocytákon belül a CD3-/CDl6+/CD56+ immunfenotípus alapján azonosíthatók, bár a markerek finomabb analízisével további NK-alcsoportokat is elkülöníthetünk. A CD$56 \mathrm{dim} / \mathrm{CD} 16+$ alcsoport perforinban és granzimban gazdag, ennek megfelelően erős cytotoxicus potenciállal bír. Ezzel szemben a CD56bright/CDl6- szubpopuláció elsősorban citokineket termel, és szabályozófunkcióval rendelkezik [30, 31].

Az NK-sejt-aktivitást is megmérhetjük in vitro, mely a cytotoxicus kapacitást vizsgálja. A K562-sejtvonalból ké-
3. táblázat A klasszikus és az alternatív útvonal összkomplement-aktivitási, valamint a komplementfaktor-3 és -4-vizsgálat eredményeinek értékelése komplementfaktor-deficientiák esetén

\begin{tabular}{lllll}
\hline CH50 & AH50 & C3 & C4 & Hiányzó komplementkomponens \\
\hline 0 & $\mathrm{~N}$ & $\mathrm{~N}$ & $\mathrm{~N}$ & $\mathrm{Clq}, \mathrm{Clr}, \mathrm{Cls}, \mathrm{C} 2$ \\
0 & 0 & $\downarrow \downarrow$ & $\mathrm{N}$ & $\mathrm{C} 3$ \\
0 & $\mathrm{~N}$ & $\mathrm{~N}$ & $\downarrow \downarrow$ & $\mathrm{C} 4$ \\
$\mathrm{~N}$ & 0 & $\mathrm{~N}$ & $\mathrm{~N}$ & $\mathrm{~B}, \mathrm{D}, \mathrm{P}$ \\
0 & 0 & $\mathrm{~N}$ & $\mathrm{~N}$ & $\mathrm{C} 5, \mathrm{C} 6, \mathrm{C} 7, \mathrm{C} 8, \mathrm{C} 9$ \\
\hline
\end{tabular}

$0=$ nem mérhető aktivitás; AH50 = az alternatív útvonal összkomplement-aktivitása; $\mathrm{CH} 50$ = a klasszikus útvonal összkomplement-aktivitása; $\mathrm{N}$ = referenciatartományon belül

szített szuszpenzióhoz adva a beteg NK-sejtjeit, a károsodott target sejtekből a jelöléshez használt radioaktív ${ }^{51} \mathrm{Cr}$ vagy a laktát-dehidrogenáz enzim kiszabadul. A cytotoxicus aktivitásra lehet következtetni a CDl07a (LAMP1, lizoszómaasszociált membránprotein-1) sejtfelszínre kerüléséből is. Ennek előnye, hogy felszíni jelöléssel együtt végezve az NK és CD8+ cytotoxicus sejtek aktivitása külön is vizsgálható. Hátránya, hogy perforindeficientiában nem mutat eltérést $[2,18,20,32]$.

\section{A TLR-szignalizáció defektusainak vizsgálata}

A mintázatfelismerő receptorok jelátviteli útvonalában található defektusokat a beteg véréből szeparált mononukleáris sejteken vizsgálhatjuk. Megfeleló ligand választásával egy adott TLR-útvonal aktiválható (például lipopoliszachariddal a TLR4, flagellinnel a TLR5, CpG-vel a TLR9). Zavar esetén a sejtek felülúszójában a gyulladásos citokinek megjelenése elmarad [2].

\section{Az autoinflammatoricus szindrómák}

Ebben a betegségcsoportban a laboratóriumi teszteknek kevesebb szerep jut, a lázas epizódok alatt mérhető magas CRP vagy más gyulladásos markeren kívül alig van jelentőségük. A hiper-IgD-szindróma (mevalonát-kináz-hiány) az egyetlen betegség, amelynek diagnosztizálásában a genetikai teszteken kívül az in vitro vizsgálatoknak hasznuk van. A hiper-IgD-szindróma név félrevezetó kissé, a betegek nagyjából 30\%-ában ugyanis nem emelkedett az immunglobulin D szintje. Az enzimhiány miatt felszaporodó mevalonsav miatt a vizeletben fokozódik az ürítés, ami az esetek nagy többségében kimutatható $[33,34]$.

Anyagi támogatás: A közlemény megírásához a szerző anyagi támogatásban nem részesült.

A cikk végleges változatát a szerző elolvasta és jóváhagyta.

Érdekeltségek: A szerzőnek nincsenek érdekeltségei. 


\section{Köszönetnyilvánítás}

Köszönöm Dr. Baráth Sándornak (Debreceni Egyetem, ÁOK, Laboratóriumi Medicina Intézet) az áramlási citometrián alapuló vizsgálatokhoz, illetve értékelésükhöz nyújtott segítséget.

\section{Irodalom}

[1] Long MP, Sanford WK, Bluth HM. Immunodeficiency disorders. In: McPherson RA, Pincus MR. (ed.) Henry's clinical diagnosis and management by laboratory methods. 23rd edn. Elsevier, Philadelphia, PA, 2017; pp. 983-992.

[2] Rosenzweig SD, Fleisher TA. Overview of laboratory studies for evaluating primary immune deficiency disorders. In: Sullivan KE, Stiehm ER. (eds.) Stiehm's immune deficiencies. Elsevier, London, 2014; pp. 61-72.

[3] Picard C, Bobby Gaspar H, Al-Herz W, et al. International Union of Immunological Societies: 2017 Primary Immunodeficiency Diseases Committee report on inborn errors of immunity. J Clin Immunol. 2018; 38: 96-128. [Epub 2017 Dec 11]

[4] Bousfiha A, Jeddane L, Picard C, et al. The 2017 IUIS phenotypic classification for primary immunodeficiencies. J Clin Immunol. 2018; 38: 129-143. [Epub 2017 Dec 11]

[5] Jolles S, Borrell R, Zouwail S, et al. Calculated globulin (CG) as a screening test for antibody deficiency. Clin Exp Immunol. 2014; 177: 671-678.

[6] Bright PD, Rooney N, Virgo PF, et al. Laboratory clues to immunodeficiency; missed chances for early diagnosis? J Clin Pathol. 2015; 68: 1-5.

[7] McPherson RA, Riley SR, Massey HD. Laboratory evaluation of immunoglobin function and humoral immunity. In: McPherson RA, Pincus MR. (eds.) Henry's clinical diagnosis and management by laboratory methods. 23rd edn. Elsevier, Philadelphia, PA, 2017; pp. 913-928.

[8] O'Gorman MR. Recent developments related to the laboratory diagnosis of primary immunodeficiency diseases. Curr Opin Pediatr. 2008; 20: 688-697.

[9] Park MA, Li JT, Hagan JB, et al. Common variable immunodeficiency: a new look at an old disease. Lancet 2008; 372: 489502.

[10] Frasch CE. Immune responses to polysaccharide and conjugate vaccines. In: Detrick B, Hamilton RG, Folds JD. (eds.) Manual of molecular and clinical laboratory immunology. 7 th edn. ASM Press, Washington, DC, 2006; pp. 434-443.

[11] Lepow ML, Hughes PA. Corynebacterium diphtheriae and Clostridium tetani: immune response and diagnostic methods. In: Detrick B, Hamilton RG, Folds JD. (eds.) Manual of molecular and clinical laboratory immunology. 7th edn. ASM Press, Washington, DC, 2006; pp. 444-447.

[12] Abraham RS, Aubert G. Flow cytometry, a versatile tool for diagnosis and monitoring of primary immunodeficiencies. Clin Vaccine Immunol. 2016; 23: 254-271

[13] Bonilla FA, Barlan I, Chapel H, et al. International consensus document (ICON): common variable immunodeficiency disorders. J Allergy Clin Immunol Pract. 2016; 4: 38-59.

[14] Malphettes M, Gérard L, Carmagnat M, et al. Late-onset combined immune deficiency: a subset of common variable immunodeficiency with severe T cell defect. Clin Infect Dis. 2009; 49: $1329-1338$.

[15] Kanegane H, Hoshino A, Okano T, et al. Flow cytometry-based diagnosis of primary immunodeficiency diseases. Allergol Int. 2018; 67: 43-54.
[16] Seyama K, Nonoyama S, Gangsaas I, et al. Mutations of the CD40 ligand gene and its effect on CD40 ligand expression in patients with X-linked hyper IgM syndrome. Blood 1998; 92: 2421-2434.

[17] Boldt A, Bitar M, Sack U. Flow cytometric evaluation of primary immunodeficiencies. Clin Lab Med. 2017; 37: 895-913.

[18] Locke BA, Dasu T, Verbsky JW. Laboratory diagnosis of primary immunodeficiencies. Clin Rev Allergy Immunol. 2014; 46: 154168.

[19] Chiarini M, Zanotti C, Serana F, et al. T-cell receptor and K-deleting recombination excision circles in newborn screening of T- and B-cell defects: review of the literature and future challenges. J Public Health Res. 2013; 2: 9-16.

[20] Riley RS. Laboratory evaluation of the cellular immune system. In: McPherson RA, Pincus MR. (eds.) Henry's clinical diagnosis and management by laboratory methods. 23rd edn. Elsevier, Philadelphia, PA, 2017; pp. 890-912.

[21] Soltész B, Tóth B, Sarkadi AK, et al. The evolving view of IL17-mediated immunity in defense against mucocutaneous candidiasis in humans. Int Rev Immunol. 2015; 34: 348-363.

[22] van Eeden SF, Klut ME, Walker BA, et al. The use of flow cytometry to measure neutrophil function. J Immunol Methods 1999; 232: $23-43$.

[23] Gibson C, Berliner N. How we evaluate and treat neutropenia in adults. Blood 2014; 124: 1251-1258.

[24] van den Berg JM, Kuijpers TW. Educational paper: defects in number and function of neutrophilic granulocytes causing primary immunodeficiency. Eur J Pediatr. 2011; 170: 1369-1376.

[25] Heinzl MW, Schönbacher M, Dauber EM, et al. Detection of granulocyte-reactive antibodies: a comparison of different methods. Vox Sang. 2015; 108: 287-293.

[26] Autrel-Moignet A, Lamy T. Autoimmune neutropenia. Presse Med. 2014; 43: el05-ell8.

[27] Elbim C, Lizard G. Flow cytometric investigation of neutrophil oxidative burst and apoptosis in physiological and pathological situations. Cytometry A 2009; 75: 475-481.

[28] Massey HD, McPherson RA, Huber AS, Jenny SN. Mediators of inflammation: Complement. In: McPherson RA, Pincus MR. (eds.) Henry's clinical diagnosis and management by laboratory methods. 23rd edn. Elsevier, Philadelphia, PA, 2017; pp. 929943.

[29] Botto M, Kirschfink M, Macor P, et al. Complement in human diseases: lessons from complement deficiencies. Mol Immunol. 2009; 46: 2774-2783.

[30] Poli A, Michel T, Thérésine M, et al. CD56 $6^{\text {bright }}$ natural killer (NK) cells: an important NK cell subset. Immunology 2009; 126: $458-465$.

[31] Orange JS. Human natural killer cell deficiencies. Curr Opin Allergy Clin Immunol. 2006; 6: 399-409.

[32] Whiteside TL. Measurement of NK-cell activity in humans. In: Detrick B, Hamilton RG, Folds JD. (eds.) Manual of molecular and clinical laboratory immunology. 7th edn. ASM Press, Washington, DC, 2006; pp. 296-300.

[33] Sag E, Bilginer Y, Ozen S. Autoinflammatory diseases with periodic fevers. Curr Rheumatol Rep. 2017; 19: 41.

[34] Ozen S, Bilginer Y. A clinical guide to autoinflammatory diseases: familial Mediterranean fever and next-of-kin. Nat Rev Rheumatol. 2014; 10: 135-147.

(Nagy Gábor dr., Debrecen, Nagyerdei krt. 98., 4032 e-mail: nagy.gabor@unideb.hu) 